\title{
Effects of age and steroid treatment on prostaglandin production by the rat uterus in relation to implantation
}

\author{
Carol Brown*, R. G. Gosden† and N. L. Poyser \\ Department of Pharmacology, University Medical School, Edinburgh EH8 9JZ and \\ $\nmid$ Department of Physiology, University Medical School, Edinburgh EH8 9AG, U.K.
}

\begin{abstract}
Summary. Prostaglandin (PG) production by the uterus of ovariectomized virgin rats, with and without replacement steroid therapy, was compared in animals aged 4-5 and 13-14 months. The synthesizing capacities of the uterus for PGE-2, PGF-2 $\alpha$. 6-ketoPGF- $1 \alpha$ and thromboxane (TX) B-2 (expressed as the amounts synthesized per mg protein by the homogenized tissue during a 90 -min incubation) were significantly lower in the ageing uteri than in young uteri. The PG and TX synthesizing capacities of the young uteri, but not of the ageing uteri, were stimulated by sequential treatment with oestradiol and progesterone implants. Tissue concentrations in and release from the uteri of PGE-2, but not of PGF-2 $\alpha$, were significantly lower in ageing rats than in younger rats, and occurred irrespective of the hormonal status. Treatment with steroids did not stimulate the tissue concentrations in or release from the uterus of PGE-2 or PGF- $2 \alpha$ in young or ageing rats. Since PGs, particularly PGE-2, produced by the rat uterus have been implicated as mediators of the implantation process, reduced production of PGE-2 by the ageing uterus may explain the lower implantation rate and the consequent reduction in fertility of ageing rats.
\end{abstract}

\section{Introduction}

Litter size in laboratory rodents is maximal at the 2 nd or 3 rd pregnancy and declines progressively thereafter until fertility is totally and irreversibly lost in middle age at 1-2 years of age (Ingram, Mandl \& Zuckerman, 1958; Biggers, Finn \& McLaren, 1962). A major cause of this infertility has been shown to be loss of uterine ability to support implantation and development of embryos (Talbert, 1977). During the phase when reproductive capacity is being lost, there is a marked reduction in the ability of the ageing uterus to respond to decidualizing stimuli, even when priming levels of oestrogen and progesterone are maintained (Finn, 1966; Maibenco \& Krehbiel, 1973; Shapiro \& Talbert, 1974; Holinka \& Finch, 1977). The impaired uterine response might be a significant cause of early implantation failure, although it has been suggested that the effect of age on decidualization induced by embryos is less severe than is indicated by artificial stimuli (Finch \& Holinka, 1982). Decidualization is preceded by, and possibly dependent on, increased capillary permeability (Psychoyos, 1973), a process which has also been shown to be reduced in ageing pregnant hamsters (Parkening \& Soderwall, 1973).

Several experiments have implicated prostaglandins (PGs) in the control of endometrial vascular changes associated with implantation in the rat. Indomethacin treatment delays the localized increase in capillary permeability in the endometrium (Kennedy, 1977; Phillips \& Poyser,

* Present address: Department of Biochemical Endocrinology, Chelsea Hospital for Women, Dovehouse Street, London SW3 6LT, U.K. 
1981). The concentrations of PGE-2, PGF- $2 \alpha$ and 6-oxo-PGF-1 $\alpha$ (which reflects PGI-2 synthesis) are increased at the sites of increased capillary permeability compared with other areas of endometrium (Kennedy, 1977; Kennedy \& Zamecnik, 1978). However, of these 3 PGs (i.e. PGE-2, PGF-2 $\alpha$ and PGI-2), only PGE-2 increases capillary permeability in the uterus of rats sensitized for the implantation process (Kennedy, 1979a, b).

Decidualization induced by artificial stimuli is also inhibited or reduced by indomethacin, while PGE-2, PGF-2 $\alpha$, PGI-2 and 9,11-epoxymethano-PGH-2 (a thromboxane A-2 receptor agonist) each induce decidualization of the suitably primed rat uterus (Tobert, 1976; Sananes, Baulieu \& Le Goascogne, 1976, 1981; Kennedy \& Lukash, 1982; Miller \& Morchoe, 1982a, b). Arachidonic acid, but not oleic, palmitic or $\omega$-dihomo- $\gamma$-linolenic acids, applied to a suitably primed uterus also induces decidualization, an action prevented by indomethacin (Sananes et al., 1981). In addition, the intraluminal administration of sesame oil to a rat uterus sensitized for decidualization increases the endometrial concentrations of PGE and PGF within 5 min (Kennedy \& Lukash, 1982). All these studies suggest that, at the time of implantation in the rat, the initial increase in capillary permeability is due to an increase solely in PGE-2 production within the endometrium, while the subsequent decidualization of the endometrium may be due to the increased local production of one or more PGs of the 2-series (including TXA-2). Defective production of these compounds by the uterus may explain the reduced responsiveness of the ageing uterus to the implantation stimulus. Consequently, PG production by the uterus has been compared in ovariectomized young adult and middle-aged rats under basal conditions, in which there was no hormone replacement, and after treatment with steroids to mimic the endocrine conditions preceding implantation, to investigate whether ageing has any significant effect on PG production by the uterus.

\section{Materials and Methods}

Virgin female Sprague-Dawley rats were housed in thermostatically controlled rooms $\left(22 \pm 1^{\circ} \mathrm{C}\right)$ with a photoperiod of $14 \mathrm{~h}$ beginning at $05: 00 \mathrm{~h}$, and with free access to a pelleted diet and water. They were caged in small groups of 3-5 animals and studied at 4-5 months or 13-14 months of age when they weighed $230-310 \mathrm{~g}$ and $270-350 \mathrm{~g}$ respectively.

Each animal was bilaterally ovariectomized under ether anaesthesia, this being designated Day 1 of treatment. During surgery special care was taken to avoid injury to the uterus or its blood supply. Animals were then allocated randomly to the treatment or control groups according to a $2 \times 2$ factorial design. On Day 8, a Silastic tubing implant (Dow Corning Ltd, Reading, Berks, i.d. $0.155 \mathrm{~cm}$, o.d. $0.3125 \mathrm{~cm}$, length $3.0 \mathrm{~cm}$ ) was introduced subcutaneously between the scapulae under brief ether anaesthesia. Implants were sealed at each end with silicone-rubber medical-grade adhesive A (Dow Corning) and were incubated in phosphate-buffered saline $(\mathrm{pH} 7 \cdot 1)$ at $37^{\circ} \mathrm{C}$ for $12 \mathrm{~h}$ before insertion into the animal. Treatment groups were given implants containing crystalline oestradiol-17 (Sigma London Ltd, Poole, U.K.) whereas control animals received empty implants. On Day 11 the oestrogen implants were removed and replaced by implants of identical construction which contained crystalline progesterone (Sigma). The implants in control animals were renewed at the same time with another empty capsule. The steroid implants produced circulating hormone levels within the physiological range for early pregnancy: 50-100 pg oestradiol-17ß/ml, 15-60 ng progesterone/ml (R. G. Gosden \& H. M. Fraser, unpublished observations). There were no differences in circulating hormone levels between the mice in the two age groups.

Steroid-treated animals received a s.c. injection of oestradiol- $17 \beta(0.5 \mu \mathrm{g} / \mathrm{kg})$ in a vehicle composed of benzyl benzoate and arachis oil $(1: 9, \mathrm{v}: \mathrm{v})$ at about $12: 00 \mathrm{~h}$ on Day 14. Control rats received the vehicle alone. On Day 15,21-23 h after the injections, the rats were killed by a blow on the head and their uterine horns were quickly dissected out. Whole uterine horns were used as it is technically extremely difficult to obtain a pure endometrial preparation from a young ovariectomized animal. One or both uterine horns were set aside for the following experiments 
Experiment 1 : production of $P G s$ and $T X B-2$ by uterine homogenates. Freshly dissected tissue was homogenized in $5 \mathrm{ml} \mathrm{Krebs'bicarbonate} \mathrm{solution} \mathrm{(for} \mathrm{composition} \mathrm{see} \mathrm{Mitchell,} \mathrm{Poyser} \mathrm{\&} \mathrm{Wilson,}$ 1977) and $100 \mu \mathrm{l}$ were set aside for measuring the protein content by the method of Lowry, Rosebrough, Farr \& Randall (1951). The remainder of the homogenate was incubated for $90 \mathrm{~min}$ at $37^{\circ} \mathrm{C}$, and aerated with $5 \% \mathrm{O}_{2}, 95 \% \mathrm{CO}_{2}$. After incubation, the $\mathrm{pH}$ of the homogenate was lowered to 4 and the PGs and TXB- 2 were extracted by shaking 3 times with 2 volumes of ethyl acetate. The ethyl acetate fractions were combined and evaporated to dryness under reduced pressure at $45^{\circ} \mathrm{C}$. Dried samples were re-dissolved in $10 \mathrm{ml}$ ethyl acetate and stored at $-20^{\circ} \mathrm{C}$. There were 10 rats per group.

The amounts of PGs and TX formed were measured by RIA. Control experiments have shown that the recovery of PGE-2 and PGF- $2 \alpha$ is greater than $90 \%$ (Poyser \& Scott, 1980). The recoveries of 6-keto-PGF- $1 \alpha$ and TXB- 2 are $81.5 \pm 2.01 \%$ and $85.7 \pm 1.97 \%$ respectively. None of the results obtained were corrected for recovery.

Experiment 2: levels of $P G E-2$ and $P G F-2 \alpha$ in uterine tissue. Each uterine horn or pair of horns was homogenized in $5 \mathrm{ml}$ ethanol and then centrifuged at $1000 \mathrm{~g}$ for $5 \mathrm{~min}$. The supernatant fluids were transferred to flasks for evaporation to dryness at $45^{\circ} \mathrm{C}$ under reduced pressure. Each extract was dissolved in $15 \mathrm{ml}$ water and the PGs were extracted and stored as above. A small portion of the homogenate $(100 \mu \mathrm{l})$ was set aside for protein estimation by the method of Lowry et al. (1951). Sufficient of each extract was available for measuring only PGE-2 and PGF- $2 \alpha$. There were 7 animals in the group.

Experiment 3: release of $P G E-2$ and $P G F-2 \alpha$ by superfused uterine tissue. Each horn was cut open longitudinally and attached by cotton threads to the base of a $20-\mathrm{ml}$ chamber at one end to an isotonic lever under a tension of $1 \mathrm{~g}$ at the other end. The horns were superfused with Krebs' solution, pre-aerated with $5 \% \mathrm{O}_{2}, 95 \% \mathrm{CO}_{2}$, at a rate of $5 \mathrm{ml} / \mathrm{min}$ at $37^{\circ} \mathrm{C}$. After an initial period of 60 min superfusion to allow the tissue to equilibrate in the new medium, the superfusate was collected for a 10-min period (1 st collection); another 10-min collection of superfusate was made after an interval of $20 \mathrm{~min}$ ( 2 nd collection). PGs were extracted and stored as above. Sufficient of each extract was available for measuring only PGE-2 and PGE-2 $\alpha$. There were 4 animals per group.

Radioimmunoassays. The antisera used in these assays were raised in rabbits in the Department of Pharmacology, University of Edinburgh. PGE-2 was measured using an antibody which shows cross-reactivity with PGE-1 (100\%), PGA-2 (13.6\%) and PGB-2 $(260 \%)$ but has low crossreactivities with other PGs and their metabolites (Lytton \& Poyser, 1982). The limit of detection was $25 \mathrm{pg} /$ tube. PGF- $2 \alpha$ was measured by an antibody which cross-reacts with PGF- $1 \alpha(100 \%)$, but has low cross-reactivity with other PGs and their metabolites (Poyser \& Scott, 1980). The detection limit was $25 \mathrm{pg} /$ tube. Although these antibodies show cross-reactivity, the rat uterus does not synthesize significant quantities of PGE-1, PGA-2, PGB-2 or PGF-1 $\alpha$ (Poyser \& Scott, 1980). Therefore, it is probable that only PGE- 2 and $P$ GF- $2 \alpha$ are being measured in the respective radioimmunoassays. 6-Keto-PGF- $1 \alpha$ and TXB- 2 were measured by antibodies which have low crossreactivities with other PGs and PG metabolites (Poyser \& Scott, 1980; Lytton \& Poyser, 1982). The detection limits were $25 \mathrm{pg} /$ tube and $30 \mathrm{pg} /$ tube respectively. At least 2 volumes of each extract were assayed in duplicate.

The intra-assay coefficients of variation, calculated from the variation between duplicate results, for the PGE-2, PGF-2 $\alpha, 6$-keto-PGF- $1 \alpha$ and TXB-2, radioimmunoassays were $12 \cdot 6 \%$, $11 \cdot 1 \%, 9.7 \%$ and $6.1 \%$ respectively. The interassay coefficients of variation, calculated from the results obtained by including a known amount of the appropriate compound in each assay, were $9 \cdot 2 \%, 8 \cdot 6 \%, 8 \cdot 2 \%$ and $8 \cdot 0 \%$ respectively.

Statistics. The results (mean \pm s.e.m.), expressed as amounts of PG or TX per unit weight of protein or per uterus, were analysed by two-way analysis of variance and Student's $t$ test (Snecedor \& Cochran, 1967). 


\section{Results}

\section{Experiment I}

The total amount of protein in the uterus was significantly increased $(P<0.001) 1.8$-fold by ageing. As the protein content was approximately $10 \%$ of the wet weight of the uterus in young and old rats, ageing therefore increased the uterine weight $1 \cdot 8$-fold. Steroid treatment increased significantly $(P<0.05)$ the protein content of the uterus from young and old rats by a similar amount. There was no interactive effect of ageing and steroid treatment on uterine protein content (Table 1).

The amounts of PGs and TXB-2 produced per unit weight of protein by homogenates of the uterus from young and ageing rats varied in magnitude, as follows: 6-keto-PGF- $1 \alpha>$ PGF- $2 \alpha>$ PGE-2 > TXB-2 (Table 1). Production of each of these compounds was significantly lower in ageing uteri than in young uteri, and, with the exception of 6-keto-PGF-1 $\alpha$ production, was increased by steroid treatment as indicated by the Anovar test (see Table 1). However, analysis of the data individually by Student's $t$ test revealed that steroid treatment significantly increased PG and TXB-2 production only in the uteri from young animals $(P<0.01)$. Steroid treatment had no effect on PG and TXB-2 production by the old uteri. Consequently, significant interactive effects of age and treatment were revealed by Anovar for PGF-2 $\alpha(P<0.025)$ and TXB-2 $(P<0.01)$ using the non-transformed data, and a significant interactive effect $(P<0.025)$ was revealed when the data for all the PGs and TXB-2 were nested and transformed to logarithms.

Table 1. Effects of age and steroid treatment on prostaglandin (PG) and thromboxane (TX) production by homogenized rat uteri

\begin{tabular}{ccccccc}
\hline $\begin{array}{c}\text { Age } \\
\text { group }\end{array}$ & $\begin{array}{c}\text { Treatment } \\
\text { group }\end{array}$ & PGE-2 & PGF-2 $\alpha$ & 6-Keto-PGF-1 $\alpha$ & TXB-2 & $\begin{array}{c}\text { Total uterine } \\
\text { protein (mg) }\end{array}$ \\
\hline
\end{tabular}

(a)

$\mathrm{ng} / \mathrm{mg}$ protein

\begin{tabular}{lllllll}
\cline { 3 - 6 } Young & Control & $4.6 \pm 0.4$ & $6.8 \pm 1.1$ & $14.0 \pm 2.3$ & $1.9 \pm 0.3$ & $24.1 \pm 3.0$ \\
& Treated & $6.7 \pm 0.6$ & $11.1 \pm 0.9$ & $20.4 \pm 3.0$ & $3.7 \pm 0.2$ & $31.7 \pm 5.6$ \\
\hline \multirow{2}{*}{ Middle-aged } & Control & $2.8 \pm 0.2$ & $5.3 \pm 0.4$ & $10.1 \pm 1.5$ & $1.7 \pm 0.3$ & $44.3 \pm 4.6$ \\
& Treated & $3.6 \pm 0.3$ & $5.5 \pm 0.7$ & $12.4 \pm 2.0$ & $2.0 \pm 0.3$ & $51.5 \pm 2.5$ \\
\hline
\end{tabular}

(b)

ng/uterus

\begin{tabular}{llllll}
\cline { 3 - 6 } Young & Control & $104.6 \pm 11.8$ & $144.8 \pm 20.9$ & $310.3 \pm 51.5$ & $48.6 \pm 12.0$ \\
& Treated & $208.0 \pm 18.6$ & $350.9 \pm 36.9$ & $659.0 \pm 110.8$ & $114.1 \pm 6.1$ \\
\hline \multirow{2}{*}{ Middle-aged } & Control & $119.9 \pm 9.9$ & $236.7 \pm 35.0$ & $479.2 \pm 112.3$ & $78.3 \pm 17.5$ \\
& Treated & $185.7 \pm 18.5$ & $279.2 \pm 44.3$ & $642.6 \pm 120.2$ & $99.8 \pm 14.6$ \\
\hline
\end{tabular}

Values are mean \pm s.e.m. for 10 observations.

(a) Significant effects of age and treatment for PGE-2 $(P<0.01)$, PGF-2 $\alpha(P<0.01)$, TXB-2 $(P<0.001)$. Production of 6-keto-PGF-1 $\alpha$ was reduced with age $(P<0.025)$ but unaffected by treatment. Uterine protein was more abundant in aged uteri $(P<0.001)$ and after steroid treatment $(P<0.05)$.

(b) Significant effects of treatment on production of PGE-2 $(P<0.001)$, PGF- $2 \alpha(P<0.01), 6$-keto-PGF-1 $\alpha(P<$ $0.025)$ and TXB-2 $(P<0.01)$.

The total amounts of PGs and TXB-2 produced per uterus were unaffected by ageing but, as the older uteri weighed approximately 1.8-fold more than the younger uteri, PG and TXB-2 production per unit weight was less in the ageing than in the younger uteri. There was a significant stimulation of PG and TXB-2 production per uterus following steroid treatment $(P<0.025)$, and there was a significant interactive effect of age and treatment for PGE-2 $(P<0.05)$. 


\section{Experiment 2}

Uterine PGE-2 and PGF-2 $\alpha$ levels were an order of magnitude lower than the amounts produced by the incubated homogenates in Exp. 1. The uterine levels of PGE-2 were higher than those of PGF- $2 \alpha$, especially in the young rats. When expressed per mg protein, the levels of PGE-2 were significantly lower in ageing uteri than in young uteri $(P<0.001$; Table 2$)$. PGF- $2 \alpha$ levels showed a similar trend but the values were not significantly different. The total contents of PGE-2 and PGF-2 $\alpha$ were not significantly different between young and old uteri, but this was due to the larger weight of the ageing uteri compensating for the lower tissue concentration. Steroid treatment did not significantly affect the levels of PGE-2 or PGF-2 $\alpha$ in young or ageing uteri.

Table 2. Effects of age and steroid treatment on (i) levels and (ii) release of prostaglandins (PG) in rat uteri

(i) Tissue concentration

\begin{tabular}{|c|c|c|c|c|c|c|c|}
\hline \multirow[b]{2}{*}{$\begin{array}{l}\text { Age } \\
\text { group }\end{array}$} & \multirow[b]{2}{*}{$\begin{array}{l}\text { Treatment } \\
\text { group }\end{array}$} & \multirow[b]{2}{*}{ PGE-2 } & \multirow[b]{2}{*}{ PGF- $2 \alpha$} & \multicolumn{2}{|c|}{ PGE-2 } & \multicolumn{2}{|c|}{ PGF- $2 \alpha$} \\
\hline & & & & $\begin{array}{c}\text { 1st } \\
\text { collection }\end{array}$ & $\begin{array}{l}\text { 2nd } \\
\text { collection }\end{array}$ & $\begin{array}{c}\text { lst } \\
\text { collection }\end{array}$ & $\begin{array}{l}\text { 2nd } \\
\text { collection }\end{array}$ \\
\hline (a) & & \multicolumn{2}{|c|}{$\mathrm{ng} / \mathrm{mg}$ protein } & \multicolumn{4}{|c|}{$\mathrm{ng} / \mathrm{mg}$ protein } \\
\hline Young & $\begin{array}{l}\text { Control } \\
\text { Treated }\end{array}$ & $\begin{array}{l}0.459 \pm 0.070 \\
0.455 \pm 0.067\end{array}$ & $\begin{array}{l}0.270 \pm 0.051 \\
0.296 \pm 0.081\end{array}$ & $\begin{array}{l}0.433 \pm 0.151 \\
0.238 \pm 0.036\end{array}$ & $\begin{array}{l}0.422 \pm 0.134 \\
0.242 \pm 0.047\end{array}$ & $\begin{array}{l}0.212 \pm 0.045 \\
0.214 \pm 0.100\end{array}$ & $\begin{array}{l}0.139 \pm 0.046 \\
0.195 \pm 0.072\end{array}$ \\
\hline $\begin{array}{l}\text { Middle- } \\
\text { aged }\end{array}$ & $\begin{array}{l}\text { Control } \\
\text { Treated }\end{array}$ & $\begin{array}{l}0.258 \pm 0.043 \\
0.173 \pm 0.016\end{array}$ & $\begin{array}{l}0.198 \pm 0.055 \\
0.169 \pm 0.032\end{array}$ & $\begin{array}{l}0.215 \pm 0.055 \\
0.122 \pm 0.017\end{array}$ & $\begin{array}{l}0.215 \pm 0.060 \\
0.089 \pm 0.007\end{array}$ & $\begin{array}{l}0.217 \pm 0.072 \\
0.154 \pm 0.041\end{array}$ & $\begin{array}{l}0.121 \pm 0.015 \\
0.183 \pm 0.076\end{array}$ \\
\hline (b) & & \multicolumn{2}{|c|}{ ng/uterus } & \multicolumn{4}{|c|}{ ng/uterus } \\
\hline Young & $\begin{array}{l}\text { Control } \\
\text { Treated }\end{array}$ & $\begin{array}{l}11.32 \pm 1.00 \\
14.61 \pm 1.80\end{array}$ & $\begin{array}{l}7 \cdot 20 \pm 1.670 \\
9.55 \pm 2.66\end{array}$ & $\begin{array}{l}5.04 \pm 1.64 \\
3.84 \pm 0.45\end{array}$ & $\begin{array}{l}4.89 \pm 1.36 \\
3.94 \pm 0.83\end{array}$ & $\begin{array}{l}2.50 \pm 0.38 \\
3 \cdot 11 \pm 1.21\end{array}$ & $\begin{array}{r}1.59 \pm 0.38 \\
2.9 \pm 0.84\end{array}$ \\
\hline $\begin{array}{l}\text { Middle- } \\
\text { aged }\end{array}$ & $\begin{array}{l}\text { Control } \\
\text { Treated }\end{array}$ & $\begin{array}{r}11 \cdot 29 \pm 2 \cdot 11 \\
8 \cdot 48 \pm 1 \cdot 13\end{array}$ & $\begin{array}{l}8.69 \pm 2.63 \\
8.12 \pm 1.62\end{array}$ & $\begin{array}{l}4 \cdot 00 \pm 1 \cdot 16 \\
2 \cdot 77 \pm 0.30\end{array}$ & $\begin{array}{l}4.06 \pm 1.31 \\
2.07 \pm 0.22\end{array}$ & $\begin{array}{l}4.21 \pm 1.55 \\
3.70 \pm 1.15\end{array}$ & $\begin{array}{l}2 \cdot 18 \pm 0.25 \\
4 \cdot 16 \pm 1 \cdot 56\end{array}$ \\
\hline
\end{tabular}

Values are mean \pm s.e.m. for 7 (i) and 4 (ii) observations.

Significant reduction in levels of PGE-2 $(P<0.001)$ and release of PGE-2 $(P<0.05)$ in aged uteri (a).

\section{Experiment 3}

PGE-2 release from young uteri was approximately 2 -fold higher than PGF- $2 \alpha$ release. This difference was not present in ageing uteri, due to a significant decrease $(P<0.05)$ in the release of PGE-2 but not of PGF-2 $\alpha$ from ageing uteri compared to young uteri, when the results are expressed per mg protein (Table 2 ). Steroid treatment did not significantly affect PGE-2 or PGF-2 $\alpha$ release from young or ageing uteri. However, steroid treatment did tend to suppress PGE-2 release in both groups of animals.

\section{Discussion}

The present studies on rats have shown that (i) the tissue concentration of PGE-2, but not of PGF$2 \alpha$, is significantly lower in ageing uteri than in young uteri, (ii) the basal release of PGE-2, but not of PGF- $2 \alpha$, from ageing uteri is significantly lower than from young uteri, (iii) PG production by uterine homogenates (which is a measure of PG synthesizing capacity, since uterine tissue levels of PGs and metabolism of PGs by the rat uterus in the absence of $\mathrm{NAD}^{+}$are low: Poyser \& Scott, 
1980 ; Phillips \& Poyser, 1981) is significantly lower in ageing rats than in young rats, and (iv) PG synthesizing ability of the uterus is stimulated by progesterone and oestradiol treatment of young animals but not of ageing animals.

The reduced concentration in and release from ageing uteri of PGE-2 occurred irrespective of the hormonal status of the rats studied. The amounts of PGs synthesized, on a unit weight basis, by the homogenized uteri of young, ovariectomized rats treated with progesterone and oestradiol and by homogenized uteri from young, intact rats on Day 5 of pseudopregnancy or pregnancy are similar (Fenwick, Jones, Naylor \& Wilson, 1977; Phillips \& Poyser, 1981). The amounts of PGs synthesized per unit weight by homogenates of ageing uteri suitably primed for implantation are therefore less than the amounts normally synthesized per unit weight by uterine homogenates from young, intact rats at the time of implantation. Ageing has had, therefore, several significant effects on the uterus as regards PG synthesis and release.

Ageing rats have reduced fertility, a primary cause of which is a lower ability of the uterus to support implantation (see 'Introduction'). Since PGE-2 of uterine origin is apparently the main mediator in causing a local increase in capillary permeability at the site of implantation in the rat uterus (Kennedy \& Armstrong, 1981), the reduced tissue concentration in and reduced output from the ageing rat uterus of PGE-2 may be one of the factors responsible for the lower implantation rate in older rats.

It was surprising in the present study that, although steroid treatment of young, ovariectomized rats increased uterine $P G$ synthesizing ability, there was no increase in tissue concentration in or release from the uterus of PGE-2 or PGF-2 $\alpha$ following such treatment. In ovariectomized guineapigs, similar steroid treatment increases both uterine PG synthesizing capacity and uterine PG release, particularly of PGF- $2 \alpha$ (Poyser, 1983a, b). The rate-limiting step in the release of PGs from tissues is regarded to be the liberation of arachidonic acid by phospholipase $\mathrm{A}_{2}\left(\mathrm{PLA}_{2}\right)$ from phospholipids, particularly phosphatidylcholine (see Vogt, 1978), although stimulation of the phosphatidylinositol cycle may also have a role in platelets (see Lapetina, 1983). PLA $\mathrm{A}_{2}$ activity in the rat uterus is stimulated $2 \cdot 5$-fold after treatment with progesterone and oestradiol (Dey, Hoversland \& Johnson, 1982), and 2- to 4-fold during early pregnancy just before implantation (Cox, Cheng \& Dey, 1982). If the activity of PLA $\mathrm{P}_{2}$ is the sole factor in controlling arachidonic acid release, in the present study one would have expected a greater release of arachidonic acid which, together with the increase in PG synthesizing ability, should have resulted in a much greater release of PGs from the uteri of young rats after steroid treatment compared to those of ovariectomized control animals. This was not the case.

Measurements of $\mathrm{PLA}_{2}$ activity in the guinea-pig uterus have shown that, although activity increases $1 \cdot 5$-fold between Days 7 and 16 of the cycle, the potential of the enzyme for releasing arachidonic acid is more than adequate (by at least one order of magnitude) to account for the amounts of PGs released (Downing \& Poyser, 1983). It was considered, therefore, that activation of $\mathrm{PLA}_{2}$ by an appropriate stimulus is more important than the absolute activity of the enzyme in controlling arachidonic acid release in the uterus. However, once the PLA $\mathrm{P}_{2}$ has been activated and arachidonic acid has been released by the application of such a stimulus, the amounts of PGs synthesized and released are dependent on the PG synthesizing capacity of the uterus as determined by the hormonal status (Poyser, 1983b). If PLA $\mathrm{PL}_{2}$ is not activated, only basal amounts of arachidonic acid would be released, and this would result in only basal amounts of PGs being synthesized and released irrespective of the PG synthesizing capacity of the uterus. In the present study therefore, it appears that, in contrast to the guinea-pig uterus, steroid treatment did not activate PLA $_{2}$, which suggests that the presence of the blastocyst (or suitable artificial stimulus) is necessary to 'switch on' arachidonic acid release and PG synthesis in the rat uterus which has been suitably primed for implantation. Application of an artifical stimulus to a rat uterus which has been so primed increases the uterine tissue concentrations of PGE and PGF within 5 min (Kennedy \& Lukash, 1982). The magnitude of these increases would depend on the PG synthesizing ability of the uterus. As decidualization of the uterus is apparently dependent upon a local production of PGs 
(see 'Introduction'), the lack of effect of oestradiol and progesterone on the PG synthesizing ability of ageing uteri, coupled with the lower basal PG synthesizing ability of such uteri, may result in a decrease in the amounts of PGs synthesized by ageing uteri in response to a decidualizing stimulus, and hence may account for the reduction in the decidual cell reaction in the uteri of older rats. This possibility merits further study.

Reduced responsiveness of the ageing uterus to steroids, as regards the effect on PG synthesizing ability, may be the result of decreasing concentrations of uterine steroid receptors (Holinka, Nelson \& Finch, 1975; Saiduddin \& Zassenhaus, 1979; Gesell \& Roth, 1981), although not all studies have documented such an effect of ageing (Blaha \& Leavitt, 1978; Belisle, Beaudry \& Lehoux, 1982). However, there was no evidence that uterine protein production in response to treatment was reduced in ageing rats compared with young rats, suggesting that the growthpromoting effect of steroids on the uterus is not lost in the older rats. Nevertheless, it is possible that the lower PG synthesizing ability of the uterus in ovariectomized control and ovariectomized steroid-treated ageing rats may be the result of a decreased growth response of those cells concerned with synthesizing PGs at the time of implantation. In addition, since the uterus continues to grow throughout life and accumulates collagen at a disproportionate rate (Schaub, 1964/65), the increasing proportion of extracellular protein may be part of the reason why basal PG production is lower in ageing uteri than in young uteri when the results are expressed per mg protein. However, the interpretation of the reduced responsiveness to steroid treatment is not limited in this way, indicating that there is a genuine decrease in PG production by the uteri of older rats. The PG synthesizing ability of the liver and its stimulation by phenobarbitone is also reduced with ageing in rats (Morita \& Murota, 1980), suggesting that a decrease in PG production by tissues might be a generalized effect of ageing. Further study is required on this aspect.

Authentic PGs and TXB-2 were kindly supplied by the Upjohn Co., Kalamozoo, U.S.A.

\section{References}

Belisle, S., Beaudry, C. \& Lehoux, J.-G. (1982) Endocrine ageing in mice: characterization of uterine cytosolic and nuclear sex steroid receptors. Expl Geront. 17, 417-423.

Biggers, T.D., Finn, C.A. \& McLaren, A. (1962) Longterm reproductive performance of female mice. II. Variation of litter size with parity. J. Reprod. Fert. 3, 313-330.

Blaha, G.C. \& Leavitt, W.E. (1978) Uterine progesterone receptors in the aged golden hamster. J. Geront. 33, 810-814.

Cox, C., Cheng, H.C. \& Dey, S.K. (1982) Phospholipase $\mathrm{A}_{2}$ activity in the rat uterus during early pregnancy. Prostaglandins, Leukotrienes \& Med. 8, 375-382.

Dey, S.K., Hoversland, R.C. \& Johnson, D.C. (1982) Phospholipase $\mathrm{A}_{2}$ activity in the rat uterus. Modulation by steroid hormones. Prostaglandins 23, 619-630.

Downing, I. \& Poyser, N.L. (1983) Estimation of phospholipase $\mathrm{A}_{2}$ activity in guinea-pig endometrium on Days 7 and 16 of the estrous cycle. Prostaglandins, Leukotrienes \& Med. 12, 107-117.

Fenwick, L., Jones, R.L., Naylor, B., Poyser, N.L. \& Wilson, N.H. (1977) Production of prostaglandins by the pseudopregnant rat uterus in vitro, and the effect of tamoxifen, with the identification of 6-ketoprostaglandin- $\mathrm{F}_{1 x}$ as a major product. Br. J. Pharmac. 59, 191-199.
Finch, C.E. \& Holinka, C.F. (1982) Ageing and uterine growth during implantation in C57BL/6J mice. Expl Geront. 17, 235-241.

Finn, C.A. (1966) The initiation of the decidual cell reaction in the uterus of the aged mouse. J. Reprod. Fert. 11, 423-428.

Gesell, M.S. \& Roth, G.S. (1981) Decrease in rat uterine estrogen receptors during aging: physio- and immunochemical properties. Endocrinology 109, 1502-1508.

Holinka, C.F. \& Finch, C.E. (1977) Age-related changes in the decidual response of the $\mathrm{C} 57 \mathrm{BL} / 6 \mathrm{~J}$ mouse uterus. Biol. Reprod. 16, 385-393.

Holinka, C.F., Nelson, J.F. \& Finch, C.E. (1975) Effect of estrogen treatment on estradiol binding capacity in uteri of aged rats. Gerontologist 15, 30-39.

Ingram, D.L., Mandl, A.M. \& Zuckerman, S. (1958) The influence of age on litter size. J. Endocr. 17, 280285.

Kennedy, T.G. (1977) Evidence for a role of prostaglandins in the initiation of blastocyst implantation in the rat. Biol. Reprod. 16, 286-291.

Kennedy, T.G. (1979a) Prostaglandins and increased endometrial vascular permeability resulting from the application of an artificial stimulus to the uterus of the rat sensitized for the decidual cell reaction. Biol. Reprod. 20, 560-567. 
Kennedy, T.G. (1979b) Does prostaglandin I-2 mediate the increased endometrial vascular permeability which results from application of a deciduogenic stimulus to the sensitised rat uterus? Biol. Reprod. 20, Suppl. 1, 99A, Abstr.

Kennedy, T.G. \& Armstrong, D.T. (1981) The role of prostaglandins in endometrial vascular changes at implantation. In Cellular and Molecular Aspects of Implantation, pp. 349-363. Eds S. R. Glasser \& D. W. Bullock. Plenum Press, New York.

Kennedy, T.G. \& Lukash, L.A. (1982) Induction of decidualization in rats by the intra-uterine infusion of prostaglandins. Biol. Reprod. 27, 253-260.

Kennedy, T.G. \& Zamecnik, J. (1978) Concentration of 6-keto-prostaglandin $F_{1 x}$ is markedly elevated at site of blastocyst implantation in rat. Prostaglandins 16, 599-606.

Lapetina, E.G. (1983) Metabolism of inositides and the activation of platelets. Life Sci. 32, 2069-2082.

Lowry, O.H., Rosebrough, N.J., Farr, A. \& Randall, R.J. (1951) Protein measurement with the Folin phenol reagent. J. biol. Chem. 193, 265-275.

Lytton, F.D.C. \& Poyser, N.L. (1982) Concentrations of PGF- $2 \alpha$ and PGE-2 in the uterine venous blood of rabbits during pseudopregnancy and pregnancy. $J$. Reprod. Fert. 64, 421-429.

Maibenco, H.C. \& Krehbiel, R.H. (1973) Reproductive decline in aged female rats. J. Reprod. Fert. 32, 121123.

Miller, M.M. \& Morchoe, C.C.C. (1982a) Decidual cell reaction induced by prostaglandin $\mathrm{F}_{2 \alpha}$ in the mature oophorectomized rat. Cell Tissue Res. 225, 189-200.

Miller, M.M. \& Morchoe, C.C.C. (1982b) Inhibition of artificially induced decidual cell reaction by indomethacin in the mature oophorectomized rat. Anat. Rec. 204, 223-230.

Mitchell, S., Poyser, N.L. \& Wilson, N.H. (1977) Effect of p-bromophenacyl bromide, an inhibitor of phospholipase $A_{2}$, on arachidonic acid release and prostaglandin synthesis by the guinea-pig uterus in vitro. Br. J. Pharmac. 59, 107-113.

Morita, I. \& Murota, S. (1980) Effect of ageing on the prostaglandin-synthesizing system in rat liver. Prostaglandins \& Med. 4, 45-52.

Parkening, T.A. \& Soderwall, A.L. (1973) Delayed embryonic development and implantation in senescent golden hamsters. Biol. Reprod. 8, 427-434.

Phillips, C.A. \& Poyser, N.L. (1981) Studies on the involvement of prostaglandins in implantation in the rat. J. Reprod. Fert. 62, 73-81.
Poyser, N.L. (1983a) Differential stimulation of prostaglandin and thromboxane synthesizing capacities in guinea-pig uterus and ovary. Prostaglandins, Leukotrienes \& Med. 10, 163-177.

Poyser, N.L. (1983b) Effect of treating ovariectomized guinea-pigs with estradiol and progesterone on basal and A23187-stimulated release of prostaglandins from the uterus superfused in vitro. Prostaglandins, Leukotrienes \& Med. 11, 345-360.

Poyser, N.L. \& Scott, F.M. (1980) Prostaglandin and thromboxane production by the rat uterus and ovary in vitro during the oestrous cycle. J. Reprod. Fert. 60, $33-40$.

Psychoyos, A. (1973) Endocrine control of egg implantation. In Handbook of Physiology, Section 7, Vol. 2, Part 2, pp. 187-215. American Physiological Society, Washington.

Saiduddin, S. \& Zassenhaus, P. (1979) Estrous cycles, decidual cell response and uterine estrogen and progesterone receptor in Fisher 344 virgin ageing rats. Proc. Soc. exp. Biol. Med. 161, 119-122.

Sananes, N., Baulieu, E.-E. \& Le Goascogne, C. (1976) Prostaglandin(s) as inductive factor of decidualization in the rat uterus. Molec. cell. Endocr. 6, 153158.

Sananes, N., Baulieu, E.-E. \& Le Goascogne, C. (1981) A role for prostaglandins in decidualization of the rat uterus. J. Endocr. 89, 25-34.

Schaub, M.C. (1964-65) Changes of collagen in the ageing and in the pregnant uterus of white rats. Gerontologia 10, 137-145.

Shapiro, M. \& Talbert, G.B. (1974) The effect of maternal age on decidualization in the mouse. J. Geront. 29, 145-148.

Snecedor, G.W. \& Cochran, W.G. (1967) Statistical Methods, 6th edn, pp. 369-375. Iowa State University Press, Ames, Iowa.

Talbert, G.B. (1977) Ageing of the reproductive system. In Handbook of the Biology of Ageing, pp. 318-356. Eds C. E. Finch \& L. Hayflick. Van Nostrand Reinhold, New York.

Tobert, J.A. (1976) A study of the possible role of prostaglandins in decidualization using a novel surgical method for the instillation of fluids into the rat uterine lumen. J. Reprod. Fert. 4, 391-393.

Vogt, W. (1978) Role of phospholipase $A_{2}$ in prostaglandin formation. Adv. Prostaglandin and Thromboxane Res. 3, 89-95.

Received 31 August 1983 